\title{
The Emergence of Civil Society in Hobbesian Philosophy
}

\author{
Edor John Edor \\ Department of Philosophy University of Calabar, Cross River State, Nigeria. \\ Email: edorjedor@unical.edu.ng
}

\begin{abstract}
The origin of the modern state has left many scholars intellectually engaged. Sociologists, psychologists, political scientists, jurists, anthropologists, and philosophers have variously grappled with the issue of the origin of the state. Thomas Hobbes is one of the great thinkers who has contributed to the discussion on the origin of the state. Thomas Hobbes is of the view that naturally, that is, man in the state of nature, is a-social, atavistically thinking about himself alone. Because of this atomistic and solitary disposition of man in the state of nature, the society was accentuated by an unprecedented degree of rancor, acrimony and obfuscation. Given this picture of man and the pre-civil-society depicted by Hobbes, one would feel that justifying the emergence of the civil society would become difficult. This paper examines how Hobbes migrated man from the state of nature to the civil society in spite of the gory picture of him he had painted. Thomas Hobbes' theory of the origin of the state is categorized in the class of the social contract theories.
\end{abstract}

Keywords: State of Nature; Social Contract; Civil Society; Authority.

\section{INTRODUCTION}

The construct of the state of nature emerged from the political thought of seventeenth and eighteenth century Europe which formed the basis for the context of the modern state. The "state of nature" theory was propounded by an English political philosopher Thomas Hobbes. Hobbes's vision of the state of nature remains the primary assumption of modernity, vantage point from which civil society or state emerged. For Hobbes there was never a time there existed a social character in man. Against this, Hobbes held that the state of nature was the condition or the assumption upon which the idea of the modern state or civil society was constructed. In this work, we will look critically at the state of nature and eventual emergence of civil society in Hobbes.

\section{THE STATE OF NATURE}

The concept of the state of nature was elaborated by Thomas Hobbes. He argued against the political ideas of Plato, Aristotle and Aquinas. According to Aristotle, "state and village emerged from the hierarchical male-dominated family" (Barker 4). The Dutch jurist, Hugo Grotius, translated Aristotle's concept into a belief that humans, by nature, are not only "reasonable" but "social." For Grotius, men are rational and he believed that it was because people were naturally reasonable that they were able to live in harmony with one another in the society.

However, Thomas Hobbes argued against Aristotle and Grotius that no such natural order exists. According to him, philosophy is a practical study of two kinds of bodies: natural and civil. He pointed out that "natural bodies" included everything for which possesses rational knowledge of causal processes. He objected to Platonic conception that there was an objective reality that 


\section{4| Jurnal Office: Jurnal Pemikiran Ilmiah dan Pendidikan Administrasi Perkantoran}

Vol. 6 No. 2, July - December 2020, Page 123-130

corresponded to ideas and words existing there in the world of form; he considered all reality to be subjective and all societies to be created by agreements of members of such societies.

Hobbes considered the state of nature "the Natural Condition of Mankind, as concerning their Felicity and Misery" (Hobbes, 1989, p. 14). The state of nature was a condition in which people existed under conditions of "high moral density" or morality but with no "common power to keep them all in awe," (Hobbes, 1989, p. 30). He opined that the state of nature was a nonpolitical and antipolitical condition. The state of nature was primarily and fundamentally constitutive of individuals who were free and equal and who lived in natural associations such as families and households. In the state of nature, a scarcity of desired things created competition for resources, distrust "diffidence", and glory (war and conquests). According to Hobbes, the natural condition for each man was to be in a state of fear of others, resulting in personal and collective wars because of their quest for acquisition to satisfy their desire. More so, self-preservation was the necessary condition for all of his satisfactions and pleasures, and each man was equal with respect to his ability to preserve his life and realize his needs. Since each was equally able, each had an equal chance to fulfill his desires. Hobbes builds human equality not from cognitive facilities, (Gauthier, 1969, p. 42) but from an explosive concept that every human is at once vulnerable to being killed and capable of killing (Gauthier, 1969, p. 43).

Hobbes, unlike Aristotle, did not see men as naturally social. He argued that, "the natural passions of men were directed toward "good", being their self-interests and desires and that they had to be educated to see the long term best interests of everyone" (Hobbes, 1989, p. 43). To rescue men from their natural passions and aggressions and to educate them, the artificial man-state, the absolute sovereign, must be created by personal covenants or agreements.

Furthermore, the state of nature was derived not from a scientific analysis of nature but from his understanding of "human nature." He conceives the state of nature as a condition of desires and passions that creates distrust and universal enmity among people in a society where nothing is unjust: "The notions of Right and Wrong, Justice and Injustice have no place there. A place where there is no common power, there is no Law: where no Law, no Injustice" (Sabin \& Thorson, 1973, p. 387). The natural state is a state of war that "consisted not in actual fighting; but in the known disposition thereto" (Moore \& Bruder, 1990, p. 274).

Thus, "a state of war" is a condition in which each individual or group is ready to fight with the others and in which this fact is common knowledge. It is a condition in which human stagnation and misery is self-evident. Hobbes while analyzing the state of nature stated thus:

In such stateless state or condition, there is no place for industry; because the fruit thereof is uncertain; and consequently no Culture of the Earth; no Navigation, nor use of commodities that may be imported by Seas; no commodious Building; no Instruments of moving, and removing such things as require much force; no Knowledge of the face of the Earth; no account of Time; no Arts; no Letters; no Society; and which is worst of all, continually in fear, and danger of violet death; And the life of man, solitary, poor, nasty, brutish, and short (Hobbes, 1989, p. 87).

From the foregoing, Hobbes asserted that the state of nature and civil society are opposed to one another. The state of nature has a right of nature (Jus Naturale), "the liberty each man has to use his own power, as he will himself, for the preservation of his own nature, that is to say, his own life; and consequently, of doing anything which in his own judgment and reason he shall conceive to be aptest means thereto" (Moore \& Bruder, 1990, p. 274). By the right of nature, "every man has a right to everything, even to one another's body" (Moore \& Bruder, 1990, p. 274). This reinforced the wretched and dangerous condition of the state of nature.

Hobbes distinction between the state of nature and civil society became the starting point in political discuss. The state of nature, as already pointed out was the condition or the assumption upon which the idea of the modern state or civil society was constructed. It is worthy to point out at this 
juncture that some philosophers attempted a construction of a rational theory of the state which began from indigenous peoples in a state of nature being the genesis of civil society. These philosophers or political philosophers ranged from Aristotle to Locke, from Spinoza to Rousseau, and from Pufendorf to Kant. These philosophers created the natural-law theory of the modern state.

\section{THE EMERGENCE OF CIVIL SOCIETY}

The understanding of the state of nature helped Hobbes and his successors to construct the idea of civil society or as he calls it, the artificial man-state and the positive content of the law (Cassirewr, 1955, p.19). According to these philosophers, the civil society arose to correct or eliminate the shortcomings of associations between people in the state of nature. The transition from individual or family freedom and equality to civil society did not occur because of nature; rather, it took place through one or more conventions made by individuals who were interested in leaving the state of nature.With this in mind, Hobbes begins the second part of his Leviathan by stating that restraint upon themselves in which we see them live in commonwealths is the foresight of their preservation, and of a more contented life" (Nwoko, 1988, p. 56) Men, thus, form commonwealth as a necessary way to avoid the state of war.

Hobbes asserts that those to handle the affairs of government must be sovereign to oversee the actions of all men and to punish those who do not act in accordance with the law (Ogar \& Akpan, 2016). Without punishment, men will view the society as meaningless and will return to a state of war. Hobbes contends, "for the law of nature (as justice, equity, modesty, mercy and (in sum) doing to others as we will be done to) of themselves, without the terror of some power to cause them to be observed, are contrary to our natural passions, that carry us to partiality, pride, revenge, and the like" (Hobbes, 1989, p. 106). As Hobbes noted earlier, man may always be obliged to the Law of Nature in his conscience, but necessary in his actions. If there is no authority to ensure the peace and security of all, then each individual cannot guarantee that no other man will forego his part of the covenant. As such, man may as well be in the state of war, and thus his security could be threatened. Hobbes noted that man was not obliged in accordance with the Law of Nature should personal security be threatened. Hence, the authority is a necessary part of the commonwealth, for without this central figure, men will not feel bound to the civil laws. Having considered the necessity of a sovereign power, Hobbes describes the way men establish this power. He states that:

"The only way to erect such a common power as may be able to defend them from the invasion of foreign and the injuries of one another, and thereby to secure them in such sort as that by their own industry, and by the fruits of earth, they may nourish themselves and live contentedly, is to confer all their will, by plurality of voices, unto one will, which is as to say, to appoint one man or assembly of men to bear their person, and everyone to own and acknowledge himself to be author of whatsoever he that so beareth their person shall act, or cause to be acted, in those things which concern the common peace and safety, and therein to submit their wills, everyone to his will, and their judgments" (Hobbes, 1989, p. 109).

In view of this, in order to form a commonwealth, each man must sacrifice is individual right and transfer it to the sovereign. It is only through his sacrifice, Hobbes believes, that a commonwealth or civil society can be established. He opines: "This is more than consent... it is real unity of them all... made by covenant of every man with every man, in such manner as if everyman should say to every man I authorize and give up my right of governing myself to this man, or this assembly of men, on this condition, that thou give their right to him, and authorize his action in like manner" (Hobbes, 1989, p. 111). Hobbes sees leaders a representatives. While this authority must derive his power from each man's individual sacrifice, he still possesses greater power.Hobbes allocates so much power to the sovereign as he elaborate upon the structure of the commonwealth. He explains:

This done, the multitude united in one person is called a COMMONWEALTH. This is the generation of that great LEVIATHIAN, or rather mortal God to which we owe, under the Immortal God, our peace and defence. For by his authority, given by him every particular 


\section{6| Jurnal Office: Jurnal Pemikiran Ilmiah dan Pendidikan Administrasi Perkantoran}

Vol. 6 No. 2, July - December 2020, Page 123-130

man in the commonwealth, he hath the use of so much power and strength conferred on him that by terror thereof he is enabled to conform the will of them all to peace at home and mutual aids against their enemies aboard. And him consisteth the essence of the commonwealth, which (to define it) is one person, of whose act a great multitude, by mutual covenant one with another, have made themselves everyone the author, to the end he may use the strength and means of them all as think expedient, for peace and common defence. And he that carrieth this person is called SOVEREIGN, and said to have Sovereign Power; and everyone besides, his SUBJECT (Hobbes, 1989, p. 109).

Hobbes uses very strong language in describing the commonwealth and the sovereign. $\mathrm{He}$ compares the representative to a god, implying some infallibility or reverence such that the subject must support his will. Furthermore, Hobbes grants the sovereign unlimited power. When defining the commonwealth, he notes that the sovereign, "may use the strength and means of them all as he shall think expedient. "Hobbes instills his trust within the sovereign himself, for he is permitted to work according to his own will, assuming that his will is in line with that of the people. Hobbes does not take into consideration that the sovereign himself could, in fact, be corrupt. For Hobbes, this absolute authority is better than the chaos of the state of nature, and thus the sovereign is permitted to use such strong power. In view of this, Hobbes saw the force that impelled the transfer of power to an artificial state as negative necessity. Taking cognizance of the state of nature, Hobbes argued that, individuals needed a super ordinate power or super human to make and sustain a political agreement or covenant. Hobbes state as follows:

I Authorize and give up my Right in Governing myself to this artificial Man, or to this assembly of men, or community, under this condition, that thou give up thy Right to him, and Authorize all actions in like manner (Hobbes, 1989, p. 87).

Thus, the origin and foundation of government are voluntary and deliberate acts. The artificial civil society becomes legal and legitimate through consent, rather than a natural society of families or households.

Hobbes holds that it is only the artificial man-state that could end the savage state of nature and create civil society. He secured this pact and its artificial creations, the commonwealth and the sovereign, against any change or possibility of legitimate disturbance. The artificial man-state was total, absolute and eternal (Nwoko, 1988, p. 59). Hobbes concluded that rebellion against civil state broke society's basic covenant and was punishable by whatever penalty the sovereign might want, to protect his subject from a return to the original state of nature or what I will call the "stateless state". The sovereign subject who created the compact became comprehensively committed to all actions of the indivisible power of the sovereign "as if they were his own" (Hobbes, 1989, p. 187). The great liberty of the subjects depended on the silence of the sovereign's law.

However, in the early eighteenth century, John Locke analyzed the origin of the state, or "civil society," he postulated an original state of nature in which primitive humans lived on their own and were subject to neither government nor law (Locke, 1970, p. 66). As the first critical and systematic theorist of the philosophy of Liberalism and Hobbes's greatest immediate successor, John Locke took up where Hobbes left off. In 1690, Locke published Two Treatises of Government. Like Hobbes, he started with the state of nature. However, he opposed Hobbes' view that the state of nature was "solitary, poor, nasty, brutish, and short", and maintained instead that the state of nature was a happy and tolerant one. He argued that humans in the state of nature were free and equal, yet insecure and dangerous in their freedom. Furthermore, Locke rejected Hobbes' idea of the legitimacy of absolute monarchy or "absolute Arbitrary Power." He also rejected that for the sake of selfpreservation, individual ssurrendered their rights to a supreme sovereign through a social contract and that this sovereign was the source of all morality and law. Locke argued that the social contract preserved the preexisting natural rights of the individual to life, liberty, and property and that the enjoyment of individual rights led, in civil society, to the common good. According to him: "Those 
who are united into one body, and have a common established Law and Judicature to appeal to, with Authority to decide controversies between them, and punish Offenders, are in Civil Society one with another; but those who have no such common Appeal, I mean on Earth, are still in the state of Nature, each being, where there is no other, Judge for himself, and Executioner; which is, the perfect state of nature" (Locke, 1970, p. 66). Thus, individuals who joined society retained fundamental human rights drawn from natural law that related to the integrity of person and property. He accepted a right of rebellion or civil war against the despot or a tyrant, for the sole aim of society is the protection of individual right and property.

In Locke's theory, a sovereign with limited powers was the source of governmental authority. "The supreme power", Locke wrote: "You cannot take from any Man any part of his property without his own consent... it is a mistake to think that the supreme Legislative Power of any common-wealth can do what it wills, and dispose of the Estate of the Subject arbitrarily, or take any part of them at pleasure" (Locke, 1970, p. 66). Like Hobbes, he started with the state of nature. However, he opposed Hobbes' view that the state of nature was "solitary, poor, nasty, brutish, and short" and maintained instead that the state of nature was a happy and tolerant one. He argued that the humans in the state of nature are free and equal, yet insecure and dangerous in their freedom. Furthermore, Locke rejected Hobbes idea of the legitimacy of absolute monarchy or "absolute Arbitrary Power." He also rejected that for the sake of self-preservation individuals surrendered their rights to supreme sovereign through a social contract and that this sovereign was the source of all morality and law. Locke argued instead that the social contract preserved the preexisting natural rights of the individual to life, liberty, and property and that the enjoyment of individual rights led, in civil society, to the common good (Akpan, 2004). According to him:

Those who are united into one body, and have common established Law and Judicature to appeal to, with Authority to decide controversies between them, and Punish Offenders, are in Civil Society one with another; but those who have no such common Appeal, I mean on Earth, are still in the state of nature, each being, where there is no other, Judge for himself, and Executioner; which is, the perfect state of Nature (Locke, 1970, p. 66).

Thus, individuals who joined society retained fundamental rights drawn from natural law that related to the integrity of person and property (Stewart \& Dollbaum, 2017; Boyd, 2018). He accepted a right of rebellion or civil war against a despot or tyrant, for the sole aim of government is the protection of individual rights and property. In Locke's theory, a sovereign with limited powers was the source of governmental authority. "The Supreme Power," Locke wrote, "cannot take from any Man any part of his property without his consent... it is a mistake to think that the Supreme Legislative Power of any Common-wealth can do what it wills, and dispose of the Estate of the Subject arbitrarily, or take any part of them at pleasure" (Locke, 1970, p. 66). The reason for this limitation on any government was that people bring property rights into political society, which was set up specifically to protect these rights. Locke contends:

For the preservation of property being the end of government, and that for which men enter into another society, it necessarily supposes and requires, that the people should have property, without which they must be supposed to lose that by entering into society, which was the end for which they entered into it, to gross an absurdity for any man to own (Locke, 1970, p. 66).

Locke saw property rights as a natural law that existed before society was formed. Other natural rights were that of subsistence, which includes the right of each individual to the material necessities for support and comfort. Beyond subsistence rights, there were acquired natural rights. These rights included rights acquired as a result of actions and transactions that individuals had undertaken on their own initiative and right acquired when individuals had laboured on a resource or put some-thing of themselves into a resource that gave them an entitlement to those resources. They were established before the origin of political society and constrained the crown and popular will. Therefore, it was not open for government to abrogate, derogate, or reorder them based on what government thought society ought to do (Frisch, 1993; Dreitzel, 2003; Stefano, 1983). 


\section{8| Jurnal Office: Jurnal Pemikiran Ilmiah dan Pendidikan Administrasi Perkantoran}

Vol. 6 No. 2, July - December 2020, Page 123-130

Locke tied entry to political society under a central, sovereign command with the need to secure property. "The great and chief therefore, of Men uniting into Commonwealths or civil society, and putting themselves under Government, is the preservation of the state of Nature. The Civilized part of Mankind was characterized by "positive laws" that were absent in the natural state (Locke 1970, p. 66). These positive laws were a response to the natural chaos of individual assertions of passion and self- interest: "First, in the state of nature there was an established, settled, known Law, received and allowed by common consent to be the Standard of Right and Wrong, and the common

measure to decide all controversies between them. Secondly, In the state of Nature there wants a knownand indifferent judge with Authority to determine all differences according to the established Law ... Thirdly, in the state of Nature there often wants Power to back and support the sentence when right and to give it due Execution"'(Locke 1970, p. 66).

From the foregoing, therefore, it is clear that the theory of social contract is based on the consent of the individuals. It dwells on the factor of consent of the people where the structure of political obligation rests. The people are the maker of the state. This theory specifies that political authority is from social contract and the people are collectively bound to obey it so long as the government works for the general good and keeps itself within the limit laid down by the compact. According to Locke, "no one can be subjected to the political power of another without his own consent" (Locke 1970, p. 68). Furthermore, the justification of the authority of civil government is the protection of the people's property and well-being, so when such protection is no longer present, or when the leader becomes a tyrant and acts against the interest of the people, they have a right, if not an outright obligation, to resist his authority. The social compact can be dissolved and the process to create political society begun anew. Because Locke did not envision the State of Nature as grimly as did Hobbes, he can imagine conditions under which one would be better off rejecting a particular civil government and returning to state of nature, with the aim of constructing a better civil government in its place. It is therefore both the view of human nature, and the nature of morality itself, which accounts for the difference between Hobbes' and Locke's views of the social contrac

\section{DISCUSSION}

Hobbes embarked a construction of civil society with a view to avoid war and civil disorder and allow peace and tranquility to reign in society. Having seen the rebellion of parliament against Charles I as a precursor to the dissolution of the medieval structure of the age, he typified his work in response to this. Hobbes' social contact theory was an answer to the theory and reality of war or civil war in his country, Britain during his time. He attempted to proffer solution for the avoidance of civil war and turmoilin his society. To achieve this Hobbes decided that absolute obedience on the part of the subject was the only way to ensure political stability. His theory of civil contract was an attempt to bring to the fore or prove the necessity of absolute rule and absolute obedience to sovereign.

In the Hobbesian state, the sovereign, or as he called it, the Leviathan, possesses the power of life and death, the leader can get drunk with such power to the detriment of the subjects or citizens bringing to reality the aphorism, "power corrupts, and absolute power corrupts absolutely." It is lack of restraint in the exercise of power by Hobbes that made Brumhall to conclude that: "Hobbes principles are pernicious both to piety and policy and destructive to all relations of mankind, between prince and subject, father and child, master and servant, husband and wife; and they who maintained them obstinately, are fitter to live in hollow tress along with beasts, than in any Christian or political society" (Malesworth, 1966, p. 25).

White Hall, in his view, maintains that Hobbes' social contract theory or political experience was limited, based on this, his theory of civil society was artificial without a proper structure (Ramaswamy \& Mukherjee, 1999, p. 187). More so, Hobbes' conception of human nature is questionable because he was indifferent to human nature from non-representative sample of humans. 
His assertion that humans are by nature egoistic with no innate morality begs the question. Hobbes' eliminates a distinction between morality and law, they became one and the same. There are no moral obligations which are separate from our contractual obligations. Furthermore, Hobbes derogatory account of human nature was a serious suspect. It is based on this that Rousseau went on to opine that, "above all, let us not conclude with Hobbes, that because man has no idea of goodness, he must be mutually wicked" (Rousseau, 1973, p. 63). Rousseau went to conclude that naturally man possesses the sentiments of compassion rather than viciousness. Similarly, John Locke rejects Hobbes' version of the state of nature. Locke believes in "natural rights" including life, liberty and happiness whereas Hobbes asserts that there are no natural rights. As a result of Locke's more positive view of nature, he proposes a more limited social contract than does Hobbes, insisting on "preserving the individual rights of citizens against the temptation of social rulers to become tyrants" (Waller, 2016, p. 73). Again, the social contracts are no inclusive of all. As Waller states, "if you can join in the contract and you can't live up to the demand of the contract, then you aren't part of the community" (Waller, 2016, p. 141). Martha Nussabum says this is a big problem because people with life-long impairment are excluded: "the failure to deal adequately with the needs of citizens with impairments and disabilities is a serious detect in modern theories as conceive of basic political principles as a result of a contract for mutual advantage (Nussbaum, 2006, p. 24). Hobbes overestimates the importance of political institutions and underestimates the extent to which government in general relies on subject interest in obeying. Hobbes brought to the fore the fact that the division of sovereignty or sovereign authority brings about civil war. According to Hobbes, the English civil war came about bout as a result of power sharing between the Monarch and the Assembly. As a reaction, (Plamentaz, 1963) observes that the absence of shared commitment among elites and settlement of political conflict gave rise to war experienced in England. However, a great accomplishment in the Leviathan is that it appeals to those who want an argument for absolution based on secular justification. The Leviathan, like Machiavelli's The Prince, helps a free-thinking leader who wants to help the state to grow. It is based on this that Hobbes' social contract is said to have advocated for a rational interest. Addison said that Hobbes' theory upheld the fact that rational individuals form a government. On this, the government was given the responsibility to protect the property and lives of rationalist, which is being practiced by almost every government on global basis (Addison, 2011). In the same vein, the social contract theory challenges rational individuals to overthrow the government in case it violates people's rights. This provided rational interests and justifies why bad government can be overthrown today.

\section{CONCLUSION}

The paper is anchored on the emergence of civil society in Hobbes political philosophy. The following issues were addressed, which are: the state of nature in Hobbes, the emergence of civil society. The work looked at Hobbes' conception of the civil society and attempted the reason for the emergence of civil society. The state has the obligation to protect the lives and property including provision of social welfare of its citizens. With this in mind, it becomes clear that the government should be for the people and by the people, deriving from the very notion of the peoples consent, a core ideal for civil society. When the government and its leaders endorse programs which do not appeal to the masses, it could be viewed as tyrannical powers who disregard the will of the people. In the case of a long train of abuses and undermining the consent of the masses of the people, revolution will emerge as a last resort leading to the civil society returning to the state of nature, in Hobbesian parlance.

\section{REFERENCE}

Addison, T. (2011). From Conflict to Reconstruction: A Revival of the Social Contract. Wesley: Perason Education Inc. 
130 Jurnal Office: Jurnal Pemikiran Ilmiah dan Pendidikan Administrasi Perkantoran

Vol. 6 No. 2, July - December 2020, Page 123-130

Akpan, C. O. (2004). The Place of Civil Disobedience in Nigerian Democracy: A Philosophical Appraisal. Sophia: An African Journal of Philosophy, 7(1), 39-45.

Boyd, R. (2018). Between grammar and style: Adam Smith and the moral geographies of civil society. Political Geography, 67(1), 115-124.

Dreitzel, H. (2003). The reception of Hobbes in the political philosophy of the early German Enlightenment. History of European Ideas, 3, 255-289.

Frisch, M. J. (1993). The emergence of nationalism as a political philosophy. History of European Ideas, 885-890.

Hobbes, T. (1989). Leviathan. Oxford: Oxford University Press.

Locke, J. (1970). Two Treatises of Government . Cambridge: Cambridge University Press.

Malesworth, W. E. (1966). The English Work of Hobbes of Malmerbury. Vol V. Londone: Scientia Verlag Aelen.

Moore, B., \& Bruder, K. (1990). Philosophy: The Power of Ideas. Boston: MaGraw Hill.

Nussbaum, M. (2006). Frontiers of Justice. London: Belknap Press of Harvard University Press.

Nwoko, M. (1988). Basic World Political Theories. Nekede: Claretian Institute of Philosophy.

Ogar, J., \& Akpan, B. (2016). Historical Perspective on Social Justice. OmniScience: A Multidisciplinary Journal, 6(3), 39-46.

Plamentaz, J. (1963). Man and Society: A Critical Examination of Some Important Social and Political Theories from Machavelli to Marx. London: Longman Publishers.

Ramaswamy, S., \& Mukherjee, S. (1999). A History of Political Though: Plato to Marx. India: Prentice Hall.

Rousseau, J. (1973). The Social Contrac and Discourses, Trans and Into by George Cole. London: J.M. Dent tans Sons Ltd.

Sabin, G., \& Thorson, T. L. (1973). A History of Political Theory, Fourth Edition. London: IBH Publishing Co.

Stefano, C. D. (1983). Masculinity as ideology in political theory: Hobbesian man considered. Women's Studies International Forum, 6(6), 633-644.

Stewart, S., \& Dollbaum, J. M. (2017). Civil society development in Russia and Ukraine: Diverging Paths. Communist and Post-Communist Studies, 50(3), 1-14.

Waller, B. (2016). Consider Ethics: Theory and Reading. Boston: Pearson Learning Solutions Books. 